\title{
Improvement of Dolly Women Quality through the Women's School based Self-Reliance
}

\author{
Ratih Khoirunnisa*, Sayyida Saida Syarifa, Septi Ayu Azizah \\ Diponegoro University, Semarang, Indonesia \\ *ratih.khoirun.nisa27@gmail.com
}

\begin{abstract}
Indonesia has abundant human resources in terms of quantity, including women. Statistic data in 2013 mention that the numbers of Indonesian females are 49.66 percent and males are 50.34 percent from 237.641.326 peoples. However, the quality of human resources is still low viewed by the educational development index that puts the state at rank 69 from 127 countries. One proof of the quality of human resources declining in Indonesia is prostitution that continues grow. One of the prostitution areas is Dolly which located in Surabaya, East Java, Indonesia. This activity could despicable in religion and morality, also affect to the physical and psychological health of women. The important thing that must be obtained to advance insight and ethics' women is an education. Nowadays, education system that requires students to get good grades makes them depressed and cannot improve their skills. Besides, the school system that unites men and women can reduce competitive spirit within students. Students who begin adolescence and love the other also caused uncontrolled relationship. It because students spend a lot of time to have fun than study and increase their skill. To improve the moral and achievement levels, it is necessary to set up a new system for education. The new education system feasible in Dolly is women's school. In addition to containing general and moral lessons, the school also provides training facilities on a variety of skills that can help women to compete and earn a living.
\end{abstract}

Keywords: Dolly, skills, women's school

\section{Introduction}

Dolly is the name of a brothel area is located in the Jarak, Pasar Kembang, Surabaya, East Java, Indonesia. In this localization region, prostitutes displayed in the glass-walled room like window dressing. Dolly has been around since the period of the Dutch and managed by a woman of Dutch descent, known as Dolly van der Mart. Descendants of Dolly is still there in Surabaya, even though they do not manage the business. Dolly was in the middle area of the city, mingling with dense human settlements, in Putat, Surabaya. Although this localization is closed, prostitution is still going on. By the problems described before, we need a new innovation to divert these prostitutes from her job before. One of those innovations is the female school. But in this school system must be in accordance with the condition of Dolly women can fulfill their needs. According to the description above, the problem is how to align the Dolly women character, what they need and the availability of facilities and the educational system. The purpose of this study is to find out what is needed by Dolly women and get the right curriculum to optimize women's school based self-reliance system. This study is expected to find what needs to improve quality of Dolly women so that they can get a better job and compete at international level and make them live well. In this study indicators used are quality of Dolly women on morality, education and soft skills based on their ability to leave prostitution and get better job to earn a living.

\section{Literature Review}

Dolly: Dolly is the name of a brothel area that located in the Jarak, Pasar Kembang, Sawahan sub district Surabaya, East Java, Indonesia. In this localization area, prostitutes displayed in the glass-walled room like dressing window. Dolly has been around since the period of the Dutch and managed by a woman of Dutch descent, known as Dolly van der Mart.

Prostitution: According to dictionary, a prostitute is "one hired as a sexual partner"; to prostitute oneself is "to offer oneself to another as a paid sexual partner". Prostitution is thereby the act of sexual relations between a prostitute and a paying customer (Flowers, 1998). 
Education System: Education system of any society is the totally of all regularly occurring encounters, not just within the school system, in schooling, but also in the larger society, so that any encounter that occurs regularly. Based on globalization phenomenon it is necessary for us to use strategic curriculum development and education. That is mentionable which this problem will be solved with flexibility that will be shown by government, specially, those groups which active in cultural economical fields, certainly they must show flexibility in different portions of employment (Yousefy \& Baratali, 2011). The government is formally responsible about the young generation wellbeing, but at the same time it is the responsibility of all those involved in the educational process, because each teacher is the first system student interface. The attention for recruiting educated and valuable teachers is a condition for evolving and creating also a valuable working force for society. Unfortunately just a few valuable elements are really motivated to teach in the Romanian educational system (Pop, 2011).

Self-Reliance: Repeatedly, participants identified the necessity of self-reliance, often stating that they could only rely on themselves. Self-reliance is defined as supporting oneself physically, emotionally and financially. It is also characterized by the lack of other support networks (Hope, 2007).

Soft Skill: "Soft skills" was a common term in the 1960s and 1970s. Student and teachers considered the term akin to human relations, interpersonal communication, and team building, all of which encompass skills that form the foundation for building relationship. A definition of soft skills from that time would encompass listening, empathy, interpersonal communication, team building, group dynamics, sensitivity to other, compassion, integrity, and honesty (Kamin, 2013). Graduates of today need to become proficient in $21^{\text {st }}$ century workplace skills as to meet the challenges of this era. The respective skills are critical thinking and problem solving, communication, collaboration, creativity and innovation (Musa, 2011). Ramesh (2010) mentions, soft skills have some characteristics such as: 1) Soft skills are that "touchy feely stuff". 2) Soft skills are conspicuous by their absence in an individual. 3) Soft skills apply across the board to any industry. 4) Soft skills are not 'quantifiable' and tend to be subjective. 5) Soft skills are seldom taught, but often caught.

\section{Methodology}

The research was conducted in Dolly using a qualitative approach by conducting interviews and observing. Interview was conducted to Dolly women and social activist in Dolly. The method of observation was also made by observed Dolly women. To reinforce the study was done by reading literature.

\section{Result}

Research has been conducted on the condition of Dolly women by observation to the location of Dolly at Jarak, Pasar Kembang, Surabaya, East Java, and also interview with psychologist, Dolly prostitute and reading the literature about Dolly itself. This research was conducted in Putat Jaya Street Sawahan sub district, Surabaya with qualitative approach by interviewed two activists who care about Dolly women, Mr. Kartono dan Mrs. Wihdatul Ummah. Study literature also done to reinforce the research and get the following data. 
Table 1: Population by Sex and Sex Ratio in Surabaya

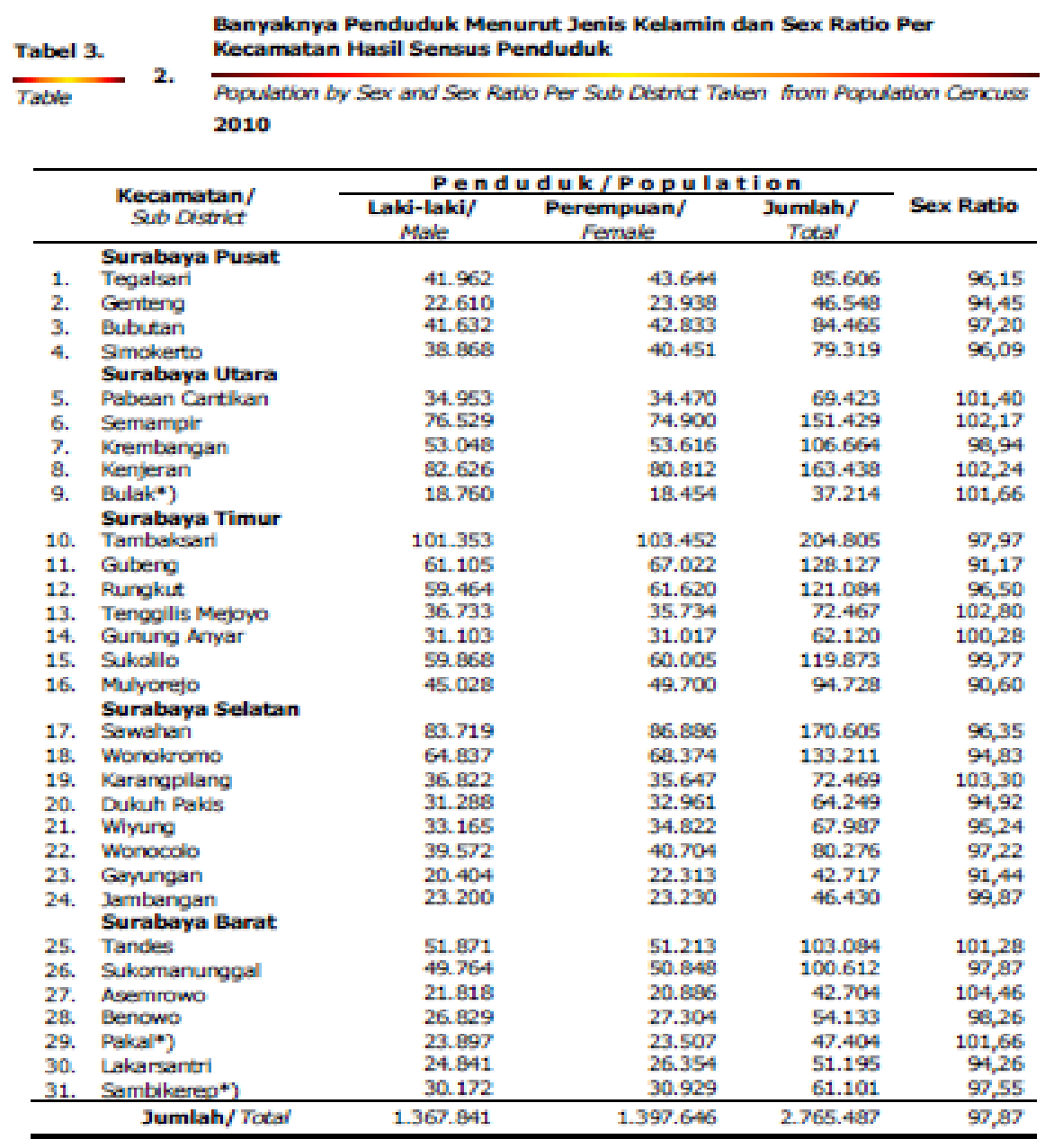

Sumber : Badan Pusat Statistik Kota Surabaye

Sowce : BPS-Statistics of Sevalaya

Chart 1: Population by Sex in Surabaya City

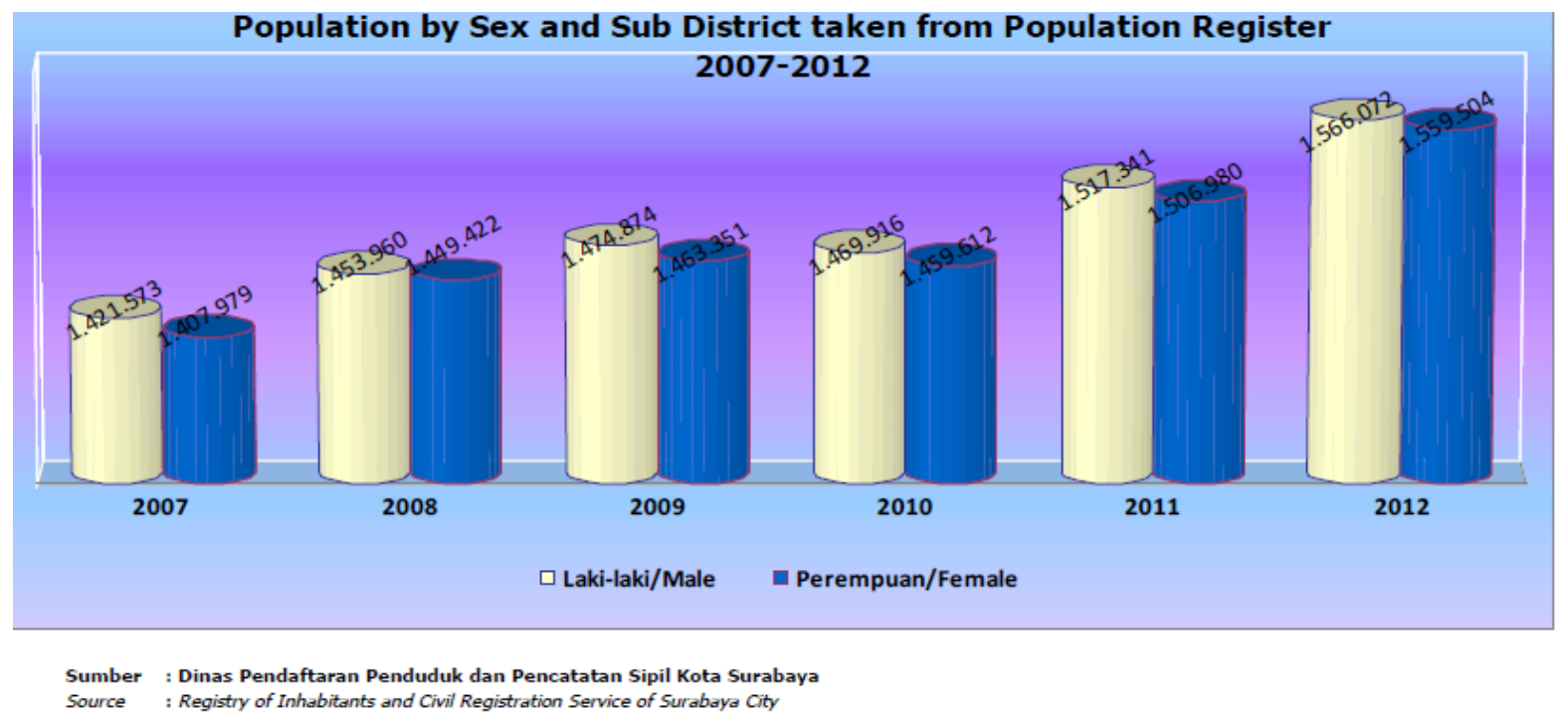




\section{Chart 2: School Facilities According to Sub District in Surabaya}

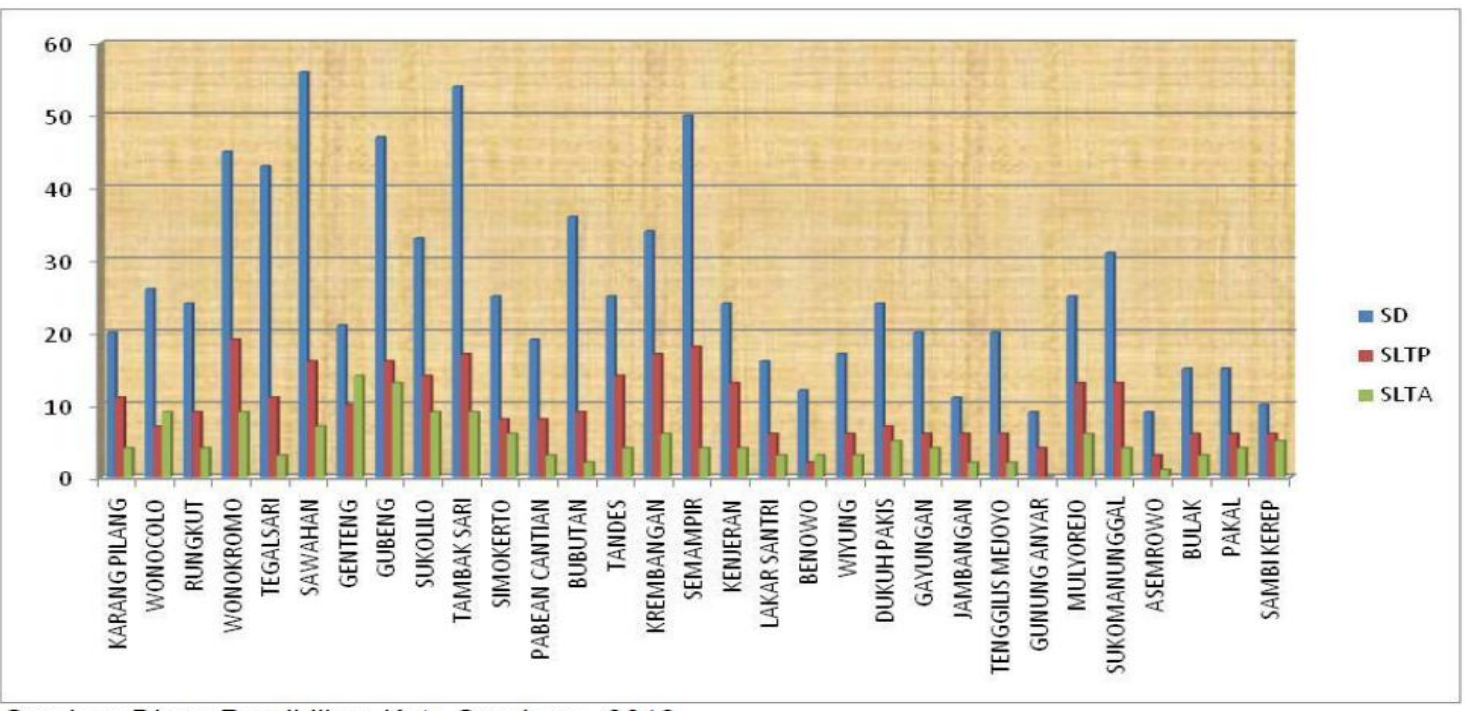

Sumber: Dinas Pendidikan Kota Surabaya, 2012.

Table 2: The Count of People According to District Based On Education Level 2012

\begin{tabular}{lllllllll}
\hline No. & District & $\begin{array}{l}\text { Total } \\
\text { Population }\end{array}$ & $\begin{array}{l}\text { Education } \\
\text { Primary } \\
\text { School }\end{array}$ & $\begin{array}{l}\text { Junior } \\
\text { High } \\
\text { School }\end{array}$ & $\begin{array}{l}\text { Senior } \\
\text { High } \\
\text { School }\end{array}$ & Academy & University & postgraduate \\
\hline 1 & Petemon & 41.435 & 16.693 & 6.074 & 14.072 & 695 & 3.466 & 435 \\
2 & Sawahan & 22.354 & 9.140 & 3.423 & 7.742 & 235 & 1.688 & 126 \\
3 & KP. Krajan & 26.804 & 12.343 & 4.078 & 8.417 & 328 & 1.533 & 105 \\
4 & Banyu Urip & 42.778 & 21.243 & 6.919 & 12.349 & 416 & 1.733 & 118 \\
5 & Putat Jaya & 45.136 & 23.777 & 7.234 & 14.072 & 383 & 1.667 & 137 \\
6 & Pakis & 39.181 & 16.736 & 5.473 & 12.312 & 649 & 3.806 & 205 \\
& Total & 217.688 & 99.932 & 33.201 & 68.964 & 2.706 & 13.893 & 1.126 \\
\hline
\end{tabular}

From the table above, we know that people of Sawahan sub district, Dolly reach education from primary school until postgraduate. In fact, the count of people that get education in Putat Jaya which be one of prostitution centre, reach 45.136 peoples. From the data we can conclude that prostitution happen in Dolly does not triggered by lack of formal education. But, this prostitution happen because the lack of moral and character education that properly taught by parents since child especially about the society with other.

Table 3: The Count of People in Sawahan sub district by Age

\begin{tabular}{lll}
\hline No. & Age Group & Total \\
\hline 1 & $1-2$ & 2.367 \\
2 & $2-4$ & 8.508 \\
3 & 5 & 3.235 \\
4 & $6-13$ & 26.355 \\
5 & 14 & 3.053 \\
6 & $15-16$ & 5.891 \\
7 & 17 & 2.685 \\
8 & $18-19$ & 5.502 \\
9 & $20-25$ & 21.039 \\
10 & $26-35$ & 43.245 \\
11 & $36-45$ & 39.540 \\
12 & $46-59$ & 33.724 \\
13 & 60 & 22.544 \\
& Total & 217.688 \\
\hline
\end{tabular}


The table above shows that the largest population in the Sawahan district is population aged 26 to 35 years who are productive age to work.

From the table 3, we can conclude that the number of people who have not worked in Sawahan districts reached 27 percent. While the population of women who are not working reach 28.819 people. This suggests that unemployment is high enough so that many people will find a job that easily obtainable. One such work is to be a prostitute. By becoming prostitutes, they can earn a high income every day without having special skills as required by the companies. Based on interviews with Mrs. Wihda, prostitutes in dolly aged between 10 to 50 years. In addition, they do not have a strong desire to move on from his profession as a prostitute. Even after localization is closed, some people in dolly still expressed their hope that the place of prostitution could open and crowded again. in addition, the government has not conducted a survey of prostitutes neatly, so that this women's school activities can not be implemented maximum.

Table 4: The Count of People in Sawahan sub district Based on Occupation

\begin{tabular}{lllll}
\hline \multirow{2}{*}{ No. } & Job & Sex & & Total \\
\hline 1 & Not yet & Male & Female & \\
2 & Farmer & 30.189 & 28.819 & 59.008 \\
3 & Fisherman & 48 & 29 & 77 \\
4 & Trader & 8 & 5 & 13 \\
5 & Official employee & 996 & 591 & 1.587 \\
6 & Indonesian National Armed Ground Forced & 3.246 & 1.171 & 4.417 \\
7 & Indonesian National Armed Ocean Forced & 191 & 4 & 195 \\
8 & Indonesian National Armed Sky Forced & 881 & 20 & 671 \\
9 & Policeman & 295 & 6 & 94 \\
10 & Retired Armed Services Officer & 818 & 16 & 311 \\
11 & Pensioner & 1.088 & 411 & 835 \\
12 & Employee & 41.836 & 12.398 & 1.499 \\
13 & Entrepreneur & 5.751 & 2.186 & 7.937 \\
14 & Laborer & 569 & 279 & 848 \\
15 & House Keeper & 13 & 154 & 167 \\
16 & Student & 19.114 & 16.855 & 35.969 \\
17 & University Student & 1.909 & 1.501 & 3.410 \\
18 & Housewife & 0 & 41.216 & 41.216 \\
19 & Doctor & 111 & 82 & 193 \\
20 & Teacher & 585 & 1.042 & 1.627 \\
21 & Medic & 21 & 149 & 170 \\
22 & Official Country & 3 & 1 & 4 \\
23 & Other & 1.456 & 1.750 & 3.206 \\
& Total & 108.986 & 108.702 & 217.688 \\
\hline & & & &
\end{tabular}

Discussion: Dolly has a great potential to become a central of women's school based characters and skills to improving the quality of women's resources. After closing declaration Localization Dolly by Surabaya government on June 18, 2014, Dolly which was once of the Southeast Asia's biggest prostitution leave $85 \%$ of former prostitutes who have no income due to the lost of job and the economic collapse. After we examine the potential of Dolly, the results we get from the interview, observation, and several books of literature shows that the condition of the human resources (former prostitutes) and government officials still have not been optimal in the improving on economical of former prostitutes that previously could get high income but now they get nothing and have no skills to compete in workplace. Some NGOs such as KAMMI (The Action Group of Indonesian Moslem Students) has conducted several approaches and training to former prostitutes in Dolly but the result is still low. This is because Dolly women still shock with their new life habit without 'instant income', and also their psychological conditions that reluctant to go out from their comfort zone. There is the role of character education. By providing characters education to Dolly women, they will have a better understanding of life and has a passion for change to be a good woman. From the explanation above, Dolly women can improve their quality of life through the school based skills where there are supporting facilities and facilitators of the training to make Dolly women are able to get an income. To arrive at this stage it is necessary to have cooperation with the 
government, NGOs, and other institutions that able to contribute in growing the character and improving the skills of Dolly women. The school also provides sustainable skills training in a long time to his students (former prostitutes) are able to apply their knowledge.

\section{Conclusion}

Dolly has a great potential in the women's improvement skills through women's school based character and self reliance, because of the former prostitute women who need guidance. However, there are elements such as government officials have not provided guidance and training to increase the capacity of Dolly women. Training or coaching that is merely referred to the social services fund that is not how nature and not permanent. This study can be used as a reference for the next research of Dolly. Practical implication of this research is the establishment a school by expands cooperation with the government, private sector and NGOs to improve the skills of women in Dolly. Future studies can observe on the management system and curriculum that can be applied to improve the quality of Dolly women, so they become moralist and independent woman.

\section{References}

BPS- Statistics of Surabaya. (2012).

Flowers, R. (1998). The Prostitution of Women and Girls.

Hope, E. A. (2007). Exploring the Family Lives of People in Prostitution: A Contextual Approach Using a Human Ecological System Model. A Dissertation Submitted to the Faculty of the Graduate School of the University of Minnesota.

Kamin, M. (2013). Soft Skills Revolution: A Guide for Connecting with Compassion for Trainers, Team, and Leaders.

Musa, F. (2011). Project- Based Learning (PjBL): Inculcating Soft Skills in $21^{\text {st }}$ Century Workplace. Procedia- Social and Behavioral Sciences, 59, 565-573.

Pop, C. (2011). A Managerial Approach for a Higher Teaching Quality. Scientific Report series Physical Education and Sport, 15 (1/2011), 826-829.

Ramesh, G. (2010). The ACE of Soft Skills: Attitude, Communication, Etiquette. India: Saurabh Printers.

Yousefy, A. \& Baratali, M. (2011). Women, Employment and Higher Education Schoolings. Procedia Social and Behavioral Sciences, 15, 3861-3869. 